San Jose State University

SJSU ScholarWorks

$12-1-2004$

\title{
A Survey of California's Nurse Practitioners' Regarding Practice, Knowledge and Atitudes of the National Asthma Management Guidelines
}

Colleen M. Hughes

San Jose State University

Follow this and additional works at: https://scholarworks.sjsu.edu/etd_projects

Part of the Pediatric Nursing Commons

\section{Recommended Citation}

Hughes, Colleen M., "A Survey of California's Nurse Practitioners' Regarding Practice, Knowledge and Atitudes of the National Asthma Management Guidelines" (2004). Master's Projects. 769.

DOI: https://doi.org/10.31979/etd.vb7u-yjsc

https://scholarworks.sjsu.edu/etd_projects/769

This Master's Project is brought to you for free and open access by the Master's Theses and Graduate Research at SJSU ScholarWorks. It has been accepted for inclusion in Master's Projects by an authorized administrator of SJSU ScholarWorks. For more information, please contact scholarworks@sjsu.edu. 


\section{SAN JOSE STATE UNIVERSITY \\ SCHOOL OF NURSING}

\section{MASTER'S PROGRAM PROJECT OPTION (PLAN B) PROJECT SIGNATURE FORM}

STUDENT NAME

SEMESTER ENROLLED

TITLE OF PROJECT
Colleen $m$ Hughes

\section{Fall 2004}

A Survey of California's

Nurse Practitioners' Reganding practice Knowledge and attitudes of the national Asthme guidelines

NAME OF JOURNAL Juaval of the American Academy of Nurse Practitioners

The project and the manuscript have been successfully completed and meet the standards of the School of Nursing University. The project demonstrates the application of professional knowledge, clinical expertise, and scholarly thinking. An abstract of the project and two copies of the manuscript are attached.

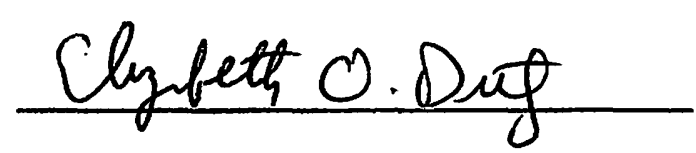

ADVISOR'S SIGNATURE

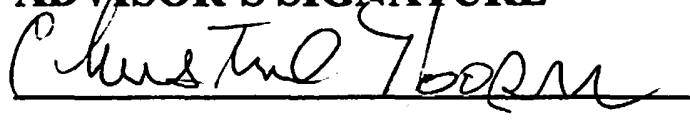

ADVISOR'S SIGNATURE
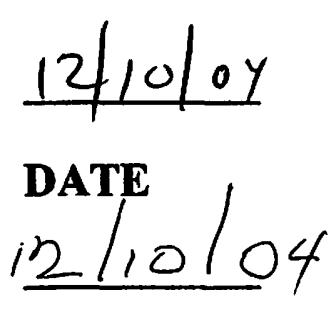

DATE

Please submit the form to the Graduate Coordinator. Attach abstract, two copies of the manuscript, and the documentation of submission to the journal (i.e., postal receipt). 
March 22, 2005

Charon Pierson, $\mathrm{PhD}, \mathrm{FAANP}$

Editor, JAANP

P. O. Box 12965

Austin, TX 78711

Dr. Pierson,

I am a graduate student at San Jose State University in the Family Nurse Practitioner Program. To fulfill the requirements for the Master of Science degree in Nursing, I completed a project for my master's requirement. The study investigated a selected group of nurse practitioners' treating pediatric asthma patients regarding their practice, knowledge and attitudes of the national asthma guidelines.

II am submitting my research study to your journal for review. This article is an original work, it has not been published previously, and it is submitted for the sole consideration of the Journal of the American Academy of Nurse Practitioners.

Dr. Elizabeth Dietz, the FNP director can also be reached for questions or concerns at or her email If you have any questions or require any further information, I will be happy to talk to you. I can be reached at home mailing address is cell or email me at concerning this matter. I look forward to hearing from you soon.

Sincerely,

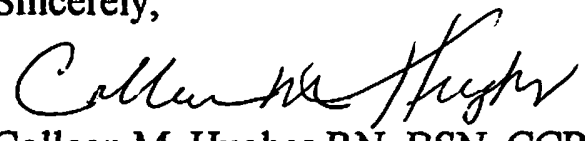

Colleen M. Hughes RN, BSN, CCRN

$$
\text { Slizatt O. Dif }
$$

Elizabeth O. Dietz, Ed.D., RN, CS-NP

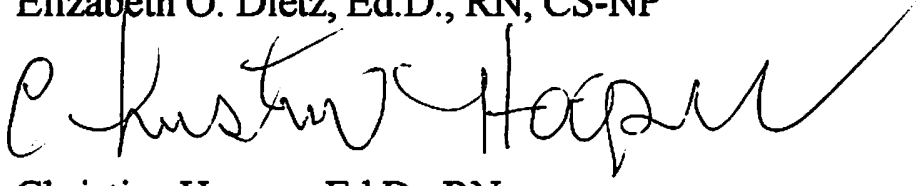

Christine Hooper, Ed.D., RN 
A SURVEY OF CALIFORNIA'S NURSE PRACTITIONERS'

REGARDING PRACTICE, KNOWLEDGE AND ATTITUDES OF

THE NATIONAL ASTHMA MANAGEMENT GUIDELINES

By:

Colleen M. Hughes, RN, BSN, CCRN
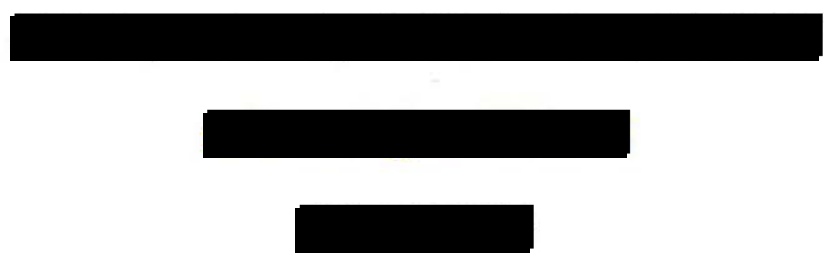

Elizabeth O. Dietz, Ed.D., RN, CS-NP

Professor San Jose State University

School of Nursing

One Washington Square

San Jose, CA 95192-0057
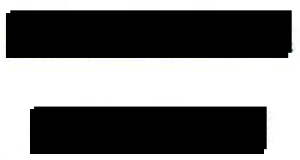

Christine Hooper, Ed.D., RN

Associate Professor San Jose State University

School of Nursing

One Washington Square

San Jose, CA 95192-0057

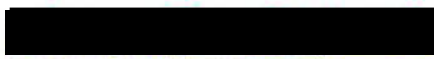




\section{Submission Statement}

The authors certify that this is original work, it has not been published previously, and it is submitted for the sole consideration of the Journal of the American Academy of Nurse Practitioners. The authors further grant permission for the Editor to send this manuscript anonymously to peer-reviewers as a part of this process.

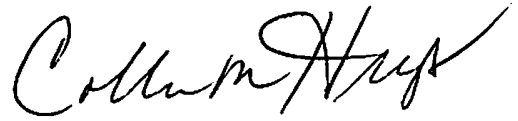

Colleen M. Hughes, RN, BSN, CCRN

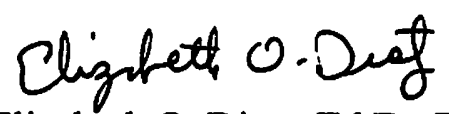

Elizabeth O. Dietz, Ed.D., RN, CS-NP
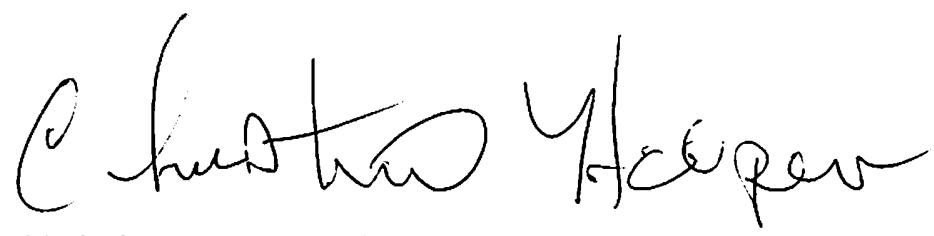

Christine Hooper, Ed.D., RN 


\begin{abstract}
Background

Pediatric asthma morbidity and mortality continues to rise in the United States despite the institution of the National Institute of Health/National Heart, Lung and Blood Institute's diagnostic and treatment guidelines. This study examines the practices, knowledge and attitudes of California's pediatric and family nurse practitioners regarding the national asthma guidelines.

Method
\end{abstract}

A quantitative mail-in survey of pediatric, pulmonary, emergent, urgent care, and family nurse practitioners was utilized to gather the data regarding the care of pediatric asthma patients. The survey collected demographic data and the NP's current asthma practices in a Likert scale format.

Results

The nurse practitioners currently practicing in California have incorporated the asthma guidelines into their practice. The guidelines were found to be evidence based, useful to practice, and maintained the individuality of patients.

Conclusion

Selected nurse practitioners in the study indicated they are staying current with the latest asthma guidelines and the pediatric asthma patients reap the benefits of the asthma guidelines.

Key words: Pediatric asthma, practice guidelines, theory of reasoned action, compliance, NAEPP 
Introduction

"Asthma is a multifactoral lung disease that causes wheezing, shortness of breath, coughing, and chest tightness. It is often associated with familiar, allergenic, socioeconomic, psychological and environmental factors. Asthma affects proportionately more children than adults, women then men, and nonwhites than whites" (CDC, Morbidity and Mortality Weekly Report, 2003, p. 382) Asthma is one of the most common chronic diseases of childhood and has become a major public health problem in the United States. This creates a substantial impact on the individual's health and quality of life. The prevalence of asthma has increased $75 \%$ overall and $74 \%$ among children 5 to 14 years of age during the years of 1980 to 1994 (Centers for Disease Control, 2004). These statistics are particularly alarming because the understanding of asthma has improved along with the medications available to control it (Wood, 2002). Asthma rates in the U.S. have increased by about $4 \%$ in 2002 bringing the total number of Americans suffering from the condition to about 16 million (CDC, 2003). Officials say they don't know why rates increased and added that minorities have more trouble controlling the condition than whites do. In the United States, nine million children have asthma (CDC, 2004) and asthma accounts for an annual loss of 14 million missed school days (CDC, 2004). A national asthma study revealed that $40 \%$ of all asthmatics have daily limitations due to their disease state (Judd, 2003).

Nearly one in thirteen children in the United States has asthma (State Services Organization, 2004). Asthma is the third-ranking cause of hospitalization among those younger than 15 years of age and the number of children dying from asthma has increased almost threefold from 93 in 1979 to 266 in 1996; these events occurred as a 
result of inappropriate or inadequate medical care. The estimated cost of treating asthma in those younger than 18 years of age is $\$ 3.2$ billion per year (CDC, 2004).

Pediatric asthma exacts a physical toll and can also influence a child's psychosocial development. Children with asthma miss three times as much school as their non-asthmatic peers, and when they are in school, they may be tired from chronic nighttime coughing that disturbs sleep. Chronically disrupted sleep can lead to more school absences and poor classroom performance. Unfortunately, these children are not living as fully and as richly as they could, if their asthma was better controlled (Michael, 2004).

\section{Purpose of the Study}

The purpose of the study was to determine from a selected group of California nurse practitioners managing pediatric asthma whether there is a relationship between their practice, knowledge, and attitudes and their adherence to the National Heart Lung and Blood Institute (NHLBI) guidelines for the diagnosis and management of asthma. The study applied the theory of reasoned action to explore the factors influencing nurse practitioners management of children with asthma.

Clinical practice guidelines are developed to translate medical research and expert opinion into recommendations for everyday practice (Ansari, et al., 2003). Despite the development of practice guidelines health care providers are often slow to incorporate these recommendations into their daily practice. Guideline adherence is crucial in translating evidence-based recommendations into improved patient outcomes. The cascade of events that occur during an acute asthma exacerbation require prompt action for stabilization of the airway to prevent hospitalization, intubations, and unnecessary 
mortality, therefore practitioners must educate their patients and implement an action plan that is concurrent with practice guidelines. Prevention of asthma exacerbations or deterioration of health is the ultimate goal of asthma treatment presented by the National Institute of Health, National Asthma Education and Prevention Program Expert Panel Report 2 (Alvey, 2001).

The management of any chronic disease especially asthma requires active involvement of the patient and their family. Healthcare providers must instruct patients and their families to use all of the prescribed treatments properly to prevent or control asthma symptoms, identify, remove and avoid triggers, and communicate needs and pertinent questions to the healthcare provider. Little is known about nurse practitioners attitudes, knowledge, and practices concerning the national asthma guidelines. How often the asthma guidelines are being used, and the factors associated with their acceptance are questions this study investigated.

\section{Research Question}

What are nurse practitioners practices, knowledge and attitudes regarding the National Institute of Health (NIH), National Heart, Lung and Blood Institute (NHLBI), National Asthma Education and Prevention Program (NAEPP) Expert Panel Report 2 (EPR 2): guidelines for the diagnosis and management of asthma and the Update on Selected Topics 2002. It was believed that nurse practitioners with positive practice, knowledge, and attitudes towards the guidelines would adhere more closely to the asthma guidelines. The research question focused on the influence of demographics, attitudes, perceptions, and knowledge of the EPR 2 on adherence to the national treatment guidelines. 


\section{Theoretical Framework}

The theoretical framework chosen to guide this research project was the well developed and tested behavioral model, the Theory of Reasoned Action (TRA) developed by Dr. Ajzen and Dr. Fishbein in 1967. The goal of this theory of human behavior is to explain how individuals make decisions about performing certain behaviors. TRA states that there are three components of the theory with the first area focusing on the person's behavioral intention (Fishbein, \& Ajzen, 1975). Intention is the main predictor and influencer of attitude. Behavioral intention is assumed to be a function of the individual's attitude toward performance of a particular behavior. People make behavioral decisions based upon a careful consideration of available information (Fishbein, \& Ajzen, 1975).

The TRA is an influential and widely used model for examining behavior and has been utilized in a variety of research studies. Nurses have been investigated in research studies using the TRA when examining their attitudes towards caring for the elderly, (McKinlay \& Cowan, 2003) patients that self poison, (McKinlay, Couston \&Cowan, 2001) nurses' intention to provide oral care (Wallace, et al., 1997) and the use of physical restraints (Werner \& Mendelsson, 2001). The TRA has been used as the theoretical framework of many other research studies ranging from predicting condom use in young people, (Sutton, McVey, \& Glanz, 1999) to the use of marijuana in young women (Morrison, Golder, Keller, \& Gillmore, 2002). Behaviors such as smoking, alcohol consumption, food choice, exercise, sexual behavior, and dieting have all been studied by applying the TRA (Puffer, 2004). The aim of this study was to use the Theory of Reasoned Action to explain variations in nurse practitioners intentions to use the national asthma guidelines. 
The Study

Subjects

The participants of this study were a selected group of nurse practitioners in Northern California consisting of family, pulmonary, urgent care, emergency, and pediatric nurse practitioners. The sample population of nurse practitioners surveyed for this research project was obtained following approval of the California Association of Nurse Practitioners' (CANP). Those NP's who are members of the organization, and on the mass mailing list for regions seven (San Francisco County) and nine (Santa Clara County) received the survey. A total of 289 surveys were mailed to the subjects. Mailing addresses of the members were provided to the researcher after the CANP reviewed the project proposal. The researchers own university's institutional review board also reviewed and approved the research study. The list of registered nurse practitioners provided by the CANP, does not separate the nurse practitioners by specialty, therefore some of the recipients of the survey were not eligible to participate in the study. Family, pediatric, urgent care, emergency and pulmonary nurse practitioners were the focus of this study for they are responsible for the assessment of and delivery of asthma care to pediatric asthma patients.

Sample

The total population of practicing nurse practitioners in the San Francisco and Santa Clara counties as per the California Board of Registered Nursing is 896. The total number of nurse practitioners in Northern California and members of CANP in the San Francisco county totals 371 , and Santa Clara county 287 . The number of nurse practitioner sampled for this study was 289 . The two counties were chosen so that the 
researcher had a usable and manageable number of participants from which to collect data.

The survey was sent to 289 of California's nurse practitioners. Forty-one completed surveys or fourteen percent of those that met the requirements for participation in the study were returned to the researcher. Another 13 completed surveys were returned to the researcher, but were not eligible because the nurse practitioner did not manage pediatric patients.

A convenience sample was utilized to gather data for this investigation. The number of subjects in the study was dependent upon the number of surveys returned by the eligible participants to the investigator. The participants were not identified within the data since none of the participants identifying data were included in the material returned to the researcher.

\section{Research Instrument}

A quantitative mail-in researcher developed survey was used to investigate the variables related to nurse practitioners practice, knowledge, and attitudes regarding the National Institute of Health (NIH), National Heart, Lung and Blood Institute (NHLBI), National Asthma Education and Prevention Program (NAEPP) Expert Panel Report 2 (EPR 2): guidelines for the diagnosis and management of asthma and the Update on Selected Topics 2002. The survey was a researcher-developed instrument with questions based on the questionnaire developed by Dr. Michael Cabana, Dr. Cynthia Rand, Dr. Oren Becher and Dr. Haya Rubin. Permission to adapt the questionnaire was obtained and the letter of permission is included in Appendix C. 
One family nurse practitioner, a pediatric nurse practitioner, a pediatrician and an asthma and allergy specialist pilot tested the survey. The questionnaire consisted of 29 items, with four categories based upon the asthma guidelines and the theory of reasoned action. Content validity of the research tool was obtained by using the NHLBI guidelines as the basis for the survey questions.

The theory of reasoned action questions used in this study was developed from constructs within the reasoned action model. Questions presented in the questionnaire were devised so that each component of the theory was addressed. The adherence to asthma guidelines questions were developed based on the National Institute of Health (NIH), National Heart, Lung and Blood Institute (NHLBI), National Asthma Education and Prevention Program (NAEPP) Expert Panel Report 2 (EPR 2): guidelines for the diagnosis and management of asthma and the Update on Selected Topics 2002.

Results

Forty-one eligible nurse practitioners or fourteen percent completed and returned the survey out of a possible 289 nurse practitioners. Question one asked about the NP's specialty. The majority of the NP's (64\%) were found to be currently working in a family practice setting, while $27 \%$ of the practitioners work in a pediatric setting, $6 \%$ in pulmonary and $3 \%$ in urgent care. Twelve percent of the participants did not answer the question.

The location of the medical practice was the second question and the responses were largely urban with $59 \%$, followed by suburban at $29 \%$ and $7 \%$ practicing in rural settings. Five percent did not respond to the question. The type of nurse practitioner practice was the focus of question 3 , with $22 \%$ of practitioners working in each of the 
areas of group practice, hospital clinics and community health center. Twenty percent of the practitioners responded that they worked in a facility labeled "other". Health maintenance organizations employed 7\% of NP's, academic health centers accounted for $5 \%$ and the final $2 \%$ are in solo practice.

Question 4 dealt with the total years in practice ranging from 1-35 years. Seventy five percent of participants indicated they had been in practice 11 years or less. The number of asthma patients on their roster was the focus of question 5 and responses ranged from 5 to 500 with the majority of practitioners having 100 asthma patients or less. Sixty seven percent of those surveyed had 50 or fewer asthmatics on their patient roster. Asthma affects nearly 5 million children, or one of 13 children in the United States. The number of NP's managing asthmatics appears lower than expected. This discrepancy can be due to survey participants estimating the number of patients rather than researching the actual number.

Question 6 asked practitioners whether they use the NHLBI asthma guidelines, Eighty one percent of NPs' responded "yes" to their use while 17\% of the NP's indicated they do not currently use the guidelines. Two percent of the participants did not answer the question. Updated topics for the diagnosis and treatment of asthma 2002 were the center of question 7. Eighty eight percent of the practitioners were aware of the updated topics in the year $2002,10 \%$ were not aware and $2 \%$ did not answer the question. Regarding the availability of the guidelines in practice as asked in question $8,78 \%$ of the 41 nurse practitioners surveyed responded that they had access to the NHBLI guidelines in their work setting. 
Question 9 asked the NP's to reveal to the researcher any and all ways in which they learned of the NLBLI asthma guidelines. How practitioners learned of the NHLBI asthma guideline varied. Nineteen of the 41 respondents reported that they learned of the guidelines from reading a copy of the NHLBI asthma guidelines. Seventeen of 41 NP's learned of the guidelines from continuing education while 13 learned of the guidelines from journal articles. Six of the NP's learned of the NHLBI guidelines from other colleagues, while 4 nurse practitioners were informed by pharmaceutical representatives, 3 responded "other" and 1 from physicians. It would appear that CANP members are proactive in regards to their practice and stay current with the latest guidelines for patient care.

Survey question 10 focused on whether the NHLBI asthma guidelines where useful to practice and $43 \%$ of NP's agreed while $44 \%$ strongly agreed. Twelve percent were undecided and $2 \%$ did not answer the question. Nurse practitioners in this survey approve of the national guidelines as derived from the information the NP's provided in question 11. Ninety eight percent of NP's surveyed had positive attitudes towards the guidelines, and $2 \%$ were undecided. Question 12 dealt with the attitudes of NP's colleagues, which were also positive with $85 \%$ agreeing or strongly agreeing, with $15 \%$ of those surveyed undecided.

Question 13 inquired as to whether the implementation of well-developed guidelines could indeed improve quality of asthmatics care. Ninety five percent of those surveyed indicated they either "agreed" or "strongly agreed". Five percent of NP's were undecided and $2 \%$ did not provide information. Question 14 asked whether the guidelines maintained individuality of the patient. Seventy three percent of the nurse practitioners 
surveyed indicated that individuality is certainly maintained, $18 \%$ were undecided and $10 \%$ did not believe this to be true. The proposition that the NHLBI asthma guidelines were evidence based was addressed in question 15 . Seventy eight percent of nurse practitioners either "agreed" or "strongly disagreed" that the NHLBI asthma guidelines are evidence based, $15 \%$ of nurse practitioners were "undecided", $5 \%$ "disagreed" and $2 \%$ did not respond to this question.

Many barriers to using national guidelines for treatments of diseases have been discussed and one that remains constant is that the guidelines are too hard to follow. Survey participants were asked in question 16 about the ease of use of the asthma guidelines and $85 \%$ "agreed" or "strongly agreed" that the guidelines where easy to follow. Question 17 asked if CANP members are comfortable using and putting into practice national guidelines. Eighty six percent of those surveyed perceive the guidelines to be helpful in their practice, $12 \%$ of NP's were undecided and $2 \%$ did not answer the question.

Questions 18 and 19 focused on smoking. The NHLBI asthma guidelines puts strong emphases on having practitioners inquire on the smoking status of the patient and their family, therefore these questions were added to the survey to research whether the NP's are perusing this topic as well. Ninety eight percent of NP's either "agreed" or "strongly agreed" with the NHLBI asthma guidelines that it is important to investigate parents smoking status or counseling parents regarding smoking, while $2 \%$ of those surveyed did not provide data to these questions.

Question 20 asked NP's whether or not they instructed patients with daily symptoms (moderate persistent asthma) to obtain daily peak flow readings. Only $24 \%$ of 
NP's instructed patients to perform daily peak flow reading $81-100 \%$ of the time. Thirty nine percent of NP's instructed patients to obtain daily peak flow monitoring $0-20 \%$ of the time. Twenty percent of nurse practitioners did not provide any information for this question.

Question 21 asked the NP's if they instruct patients with daily symptoms to avoid exposure to tobacco smoke. Controlling environmental factors and avoiding known triggers such as allergens or irritants are deemed important by the NHLBI asthma guidelines. Of the 41 survey participants $73 \%$ answered that they instruct patients to avoid tobacco smoke $81-100 \%$ of the time, $7 \%$ indicated they advise their clients $61-80 \%$ of the time and $5 \%$ of the NPs advise their patients to avoid smoke $0-20 \%$ of the time. Fifteen percent of those surveyed did not provide data for this question.

Question 22 asked how many of the NP's surveyed furnish inhaled corticosteroids patients with mild persistent asthma. Inhaled corticosteroid is the preferred treatment for mild persistent asthma. Thirty nine percent of NP's furnish inhaled corticosteroids to 81$100 \%$ of asthma patients, $24 \%$ furnish the medication to $61-100 \%$ of the patients, $7.3 \%$ of the NPs furnish the medication to $41-60 \%$ of patients, $2 \%$ to $21-41 \%$ of patients and $10 \%$ of NPs furnish medication to $20 \%$ or fewer patients. Seventeen percent of the nurse practitioners surveyed did not provide information for this question.

Question 23 asked NP's the percentage of mild persistent asthma patients that they furnished with cromolyn. $7.3 \%$ of the NPs furnish cromolyn $61-80 \%$ of patients, $9.8 \%$ of NPs furnish cromolyn to $21-61 \%$ of their patients. Fifty nine percent of NP's furnish cromolyn $20 \%$ or fewer patients. Fifteen percent of the participants did not provide information to this question. 
Question 24 required the NP's to rate the percentage of patients with mild persistent asthma that they furnish leukotriene receptor antagonists. Forty four percent provide this medication to $0-20 \%$ of their patients, $17 \%$ furnish leukotriene receptor antagonists to $21-40 \%$ of patients, while $7.3 \%$ chose provide the medication to $41-60 \%$ of their patients, $10 \%$ to $61-80 \%$ and $2 \%$ to $81-100 \%$. Twenty percent of NP's surveyed did not provide information to this question.

Comparisons can be made when evaluating questions 22, 23, and 24. Question 22 asked NP's of their practices regarding the preferred treatment option for those patients with mild persistent asthma. The preferred method of treatment (inhaled corticosteroid) was used over the two alternative medications (cromolyn and leukotriene receptor antagonist). Nurse practitioners in this survey are following the NHLBI asthma guidelines when it comes to the management of mild persistent asthma.

Item 25 of the survey questioned NP's as to whether they provided their patients with moderate persistent asthma (those with daily symptoms) daily medications. Of the 41 respondents only $53 \%$ of NP's provide daily medications to $81-100 \%$ of the patients. $15 \%$ answered $61-80 \%, 7 \%$ chose $41-60 \%$ and $10 \%$ of NP's provide daily medications to moderate persistent asthmatics $0-21 \%$. Of the survey participants, $15 \%$ of NP's did not provide data for this question. The nurse practitioners in this instance are not following the NHLBI asthma guidelines. Daily medications are required to successfully manage these patients. Low or medium dose corticosteroids as well as a long acting beta 2 agonist are the drugs of choice for this group. Alternative therapy would include they abovementioned medications and a leukotriene receptor antagonist or theophylline. 
Question 26 asked NP's the percentage of pediatric patients with moderate persistent asthma that they furnish leukotriene receptor antagonist. Thirty four percent of NP's furnish this medication to $0-20 \%$ of patients, $12 \%$ provide the medication to 21 $40 \%$ of their patients. Twenty percent of NP's furnish leukotriene receptor antagonists to $41-60 \%$ of their patients where only $7 \%$ of practitioner provide the medication to $61-80 \%$ of the patients and $12 \%$ furnish the medication to $81-100 \%$ of their moderate persistent asthma patients. Fifteen percent of the participants did not provide information for this question.

Data from question 24 and 26 can be compared to investigate the difference in use of leukotriene receptor antagonist and those suffering from mild persistent and moderate persistent asthma. It was found that NP's furnish more leukotriene receptor antagonists to those asthmatics suffering with moderate persistent asthma. This finding is in keeping with the guidelines so the CANP's are using the guidelines appropriately in this instance.

The percentage of pediatric asthma patients given a written asthma action plan was investigated in number 27 on the survey. Only $22 \%$ of NP's providing care to pediatric asthmatics gives an action plan to $80-100 \%$ of their patients. This is not in keeping with the NHLBI asthma guidelines. Seven percent of NP's provide a plan to 41$60 \%$ of patients and $10 \%$ of the NP's provide the action plan to $21-40 \%$ of their asthma patients. Twenty four percent of the survey participants provide action plans to $0-20 \%$ of their asthma patients. Fifteen percent of the NP's surveyed did not provide information to this question.

Question 28 asked nurse practitioners about whether they educate their asthma patients about their disease. Fifty nine percent responded that they educate $81-100 \%$ of 
their asthma patients. Fifteen percent responded that they educate $61-100 \%$ of their patients, $2 \%$ educate patients $41-60 \%$, and $5 \%$ for both the $21-40 \%$ and $0-20 \%$. These percentages are lower than the NHLBI asthma guidelines. Prevention of asthma exacerbations is obtained by educating patients regarding the proper use and dosing of medications, the avoidance of triggers and using the asthma action plan for the management of symptoms. If patients are not educated properly regarding their disease they are at an increased risk of complications.

Question 29 asked about the nurse practitioners intentions to use the NHLBI asthma guidelines. $88 \%$ of the NP's participating answered, "Yes" to this question, $2 \%$ answered "No", and 10\% did not answer the question.

Discussion

The data gathered for this research project supports the research question. Those nurse practitioners with a positive attitude and knowledge of the guidelines were, in fact, putting the guidelines to use in practice. Eighty percent of nurse practitioners surveyed are using the guidelines and $98 \%$ of practitioners had positive attitudes towards the guidelines. Maintaining the individuality of the patient is listed as one of the major deterrents to the use of national treatment guidelines and the CANP members do not find this to be true.

The NHLBI asthma guidelines focus on four key issues: (1) the use of peak flow monitoring, (2) educating the patient and or parent regarding the disease, (3) avoidance of triggers and (4) medications. The data gathered from this research study found that the research participants are following the guidelines related to two of the four key issues. As evidenced by the data, CANP members are instructing patients to avoid asthma triggers 
(smoke) and educate patients and parents regarding the harm of cigarette smoke. When surveyed, the nurse practitioners are using the appropriate medications to manage asthma. The proper use of inhaled corticosteroid versus the use of leukotriene receptor antagonist was supported by the research data. The issue of patient/parent education and peak flow monitoring are two components that are vital to asthma management and the asthma guidelines but are not being followed by the CANP members. Non-compliance by CANP members might be due to lack of time in the office, viewing the guidelines as merely a tool to guide practice and not a mandate. All providers managing asthma must be encouraged to comply with these vital components for the most effective management of asthma. It is agreed that the key to successful asthma management is prevention of symptoms and proactive treatment; therefore nurse practitioners might help their patients gain better control of symptoms if they would require daily peak flow monitoring in accordance with the NHLBI asthma guidelines.

Eighty percent of the nurse practitioners surveyed are using the asthma guidelines as compared to $48 \%$ of physicians using the guidelines in a 2002 study by Divertie. The nurse practitioners that support the use of the asthma guidelines also indicate that the guidelines are indeed easy to follow and do not deny the individuality of the patient. These issues have historically been seen as barriers to using clinical practice guidelines. Due to the fact that the guidelines were viewed as evidence based and reflect current practice the nurse practitioners in this study support the use of national clinical practice guidelines to manage disease conditions and improve patient outcomes. Nurse practitioners in the survey were informed of the guidelines and agreed about their ease of use although they did not always comply with the guidelines. Nurse practitioners in this 
survey do need to teach patients of their disease at each visit along with developing and action plan and the use of peak flow monitors.

Although the data did not address the reasons in which one would not use the recommended guidelines, it must be recalled that guidelines represent the best judgment of a team of experienced clinicians addressing the scientific evidence for a clinical problem and were never intended to overrule professional judgment. This component was not addressed in this survey.

Limitations

There are several limitations to this study. The survey response rate was only $14 \%$ and these participants were members of a professional organization. Adherences to asthma guidelines were based on self-report, which might not reflect actual adherence. Research evidence supports the fact that self-report can overestimate or underestimate actual practice when compared to patient surveys or chart audits.

The final limitation to the study is the validity of the research tool. The survey was a self-developed research tool adapted from a pre-existing survey. Therefore the survey had not been tested for reliability of information gained. Questions within the survey were not consistent. Nurse practitioners were surveyed regarding the medication management of patients with mild persistent asthma and moderate persistent asthma. The questions asked were not consistent when investigating the medications used to manage the mild and moderate persistent asthmatic, which prevents comparisons of how NP's manage these patients. 
Implications for practice

The results of this study have implication for interventions that will improve practice. Factors associated with adherence to the medication regimen for the control and management of asthma symptoms is one aspect in which the nurse practitioners in this study could improve. The majority in this study accepted the asthma guidelines although the medication adherence had the lowest level of compliance. By the identification of the barriers interventions can be constructed to improve adherence.

Nurse practitioner programs must instruct and educate NP students of the national guidelines as a part of asthma education to ensure that new practitioners are accustomed to incorporating national guidelines into practice. Frequent review and updates to the guidelines is another factor affecting the adherence to guidelines. Reinforcement of the asthma guidelines as part of nurse practitioner conferences and continuing education is also crucial to encourage complacency of use. Many practitioners would be more inclined to incorporate national guidelines into daily practice with the knowledge that the guidelines reflect the most current recommendations and research.

Further research of the asthma guidelines can be completed to demonstrate the association between the use of the national guidelines and the cost saving benefits of their use. This component has been identified in asthma research as a barrier to asthma guideline adherence and documentation of the saving associated with the use of national guidelines is needed. 


\section{References}

Ajzen, I., \& Fishbein, M. (1980). Understanding attitudes and predicting social behavior. Englewood Cliffs, NJ: Prentice Hall.

Alvey, D. (2001). Asthma emergency care: national guidelines summary. Heart and Lung, 30, (6) 472-474.

Ansari, M., Shlipak, M., Heidenreich, P., Ostaeyen, D., Pohl, E., Browner, W., et al. (2003). Improving guideline adherence: A randomized trail evaluating strategies to increase ß-blocker use in heart failure. Circulation, 107, 2799-2804.

Cabana, M., Rand, C., Becher, O., \& Rubin, H. (2001). Reasons for Pediatrician nonadherence to asthma guidelines. Archives of Pediatric \& Adolescent Medicine, 155, 1057-1062.

Center for Disease Control. (2004). Asthma's impact on children and adolescents. Retrieved October 5, 2004 from http://www.cdc.gov/asthma/children.htm Centers for Disease Control. Morbidity and Mortality Weekly Report. (2003). Selfreported asthma prevalence and control among adults-United States. Retrieved May 5, 2003 from http://www.cdc.gov/mmwr/preview/mmwrhtml/mm5217a2.htm

Divertie, V. (2002). Strategies to promote medication adherence in children with asthma. Maternal and Child Nursing, 27, (1) 10-19.

Fishbein, M., \& Ajzen, I. (1975). Beliefs, attitude, intention and behavior. Reading, MA: Addison-Wesley. 
Judd, D. (2003). Guidelines for the diagnosis and management of asthma: update on selected topics 2002. Journal of the American Academy of Nurse Practitioners, 15, (4) 151- 153 .

McKinlay, A., Couston, M., \& Cowan, S. (2001). Nurses' behavioural intentions towards self-poisoning patients: a theory of reasoned action, comparison of attitudes and subjective norms as predictive variables. Journal of Advanced Nursing, 34 (1) $107-116$.

McKinlay, A., \& Cowan, S. (2003). Student nurses' attitudes towards working with older patients. Journal of Advanced Nursing, 43, 298-309.

Morrison, D., Golder, S., Keller, T., \& Gillmore, M. (2002). The theory of reasoned action as a model of marijuana use: tests of implicit assumptions and applicability to high-risk young women. Psychology of Addictive Behavior, 16, 212-224.

Michael, M. (2002). Scope and impact of pediatric asthma. The Nurse Practitioner, 27, 3-6.

National Heart, Lung and Blood Institute, National Asthma Education and Prevention Program. Expert Panel Report 2: guidelines for the diagnosis and management of asthma. Bethesda MD: US Department of Health and Human Services, National Institute of Health, 1997; publication no.97-0451.

National Heart, Lung and Blood Institute, National Asthma Education and Prevention Program. Expert Panel Report: guidelines for the diagnosis and management of asthma- update of selected topics 2002. Bethesda MD: US Department of Health and Human Services, National Institute of Health, 1997; publication no National Institute of Health, 2002; publication no.02-5075 
Puffers, S. (2004). Practice nurses' intentions to use clinical guidelines. Journal of Advanced Nursing, 47, (5) 500-509.

State Services Organization. (2004). Catching your breath: Strategies to reduce environmental factors that impact asthma in children. Retrieved October 28, 2004 from http://www.sso.org/ecos/Asthma2/WorkInProgress/childhoodasthma

Sutton, S., McVey, D., \& Glanz, A. (1999). A comparative test of the theory of reasoned action and the theory of planned behavior in the prediction of condom use intentions in a national sample of English young people. Health Psychology, 18,(1) 72-81.

Wallace, K., Koeppel, K., Senko, A., Stawiaz, K., Thomas, C., \& Kosar, K. (1997). Effect of attitudes and subjective norms on intention to provide oral care to patients receiving antineoplastic chemotherapy. Cancer Nursing, 20, (1) $34-41$.

Werner, P., Mendelsson, G. (2001). Nursing staff members' intentions to use physical restraints with older people: testing the theory of reasoned action. Journal of Advanced Nursing, 35, 784-791.

Wood, R. (2002). Pediatric asthma. Journal of the American Medical Association, 288, 45-747. 
Pediatric Asthma Survey

\begin{tabular}{|c|c|c|c|c|c|}
\hline & & Frequency & Percent & $\begin{array}{l}\text { Valid } \\
\text { Percent }\end{array}$ & $\begin{array}{c}\text { Cumulative } \\
\text { Percent }\end{array}$ \\
\hline Valid & 1 PEDISURVEY & 41 & 100.0 & 100.0 & 100.0 \\
\hline
\end{tabular}

\begin{tabular}{|c|c|c|c|c|c|}
\hline \multicolumn{6}{|c|}{ Q1 SPECIALTY } \\
\hline & & Frequency & Percent & $\begin{array}{l}\text { Valid } \\
\text { Percent }\end{array}$ & $\begin{array}{c}\text { Cumulative } \\
\text { Percent }\end{array}$ \\
\hline & 1 Emergency & 0 & 0 & 0 & 0 \\
\hline \multirow{5}{*}{ Valid } & 2 FAMILY & 23 & 56.1 & 63.9 & 63.9 \\
\hline & 3 URGENT CARE & 1 & 2.4 & 2.8 & 66.7 \\
\hline & 4 PULMONARY & 2 & 4.9 & 5.6 & 72.2 \\
\hline & 5 PEDIATRIC & 10 & 24.4 & 27.8 & 100.0 \\
\hline & Total & 36 & 87.8 & 100.0 & \\
\hline Missing & System & 5 & 12.2 & & \\
\hline Total & & 41 & 100.0 & & \\
\hline
\end{tabular}

\begin{tabular}{|l|l|r|r|r|r|}
\hline \multicolumn{1}{|c|}{ Q2 LOCATION } \\
\hline & Frequency & Percent & $\begin{array}{c}\text { Valid } \\
\text { Percent }\end{array}$ & $\begin{array}{c}\text { Cumulative } \\
\text { Percent }\end{array}$ \\
\hline \multirow{3}{*}{ Valid } & 1 URBAN & 24 & 58.5 & 61.5 & 61.5 \\
\cline { 2 - 7 } & 2 SUBURBAN & 12 & 29.3 & 30.8 & 92.3 \\
\cline { 2 - 7 } & 3 RURAL & 3 & 7.3 & 7.7 & 100.0 \\
\cline { 2 - 7 } & Total & 39 & 95.1 & 100.0 & \\
\hline Missing & System & 2 & 4.9 & & \\
\hline Total & 41 & 100.0 & & \\
\hline
\end{tabular}


Nurse Practitioner Survey of National Asthma Guidelines 25

\begin{tabular}{|c|c|c|c|c|c|}
\hline \multicolumn{6}{|c|}{ Q3 PRACTICE TYPE } \\
\hline & & Frequency & Percent & $\begin{array}{l}\text { Valid } \\
\text { Percent }\end{array}$ & $\begin{array}{c}\text { Cumulative } \\
\text { Percent }\end{array}$ \\
\hline \multirow{8}{*}{ Valid } & 1 GROUP & 9 & 22.0 & 22.0 & 22.0 \\
\hline & 2 SOLO & 1 & 2.4 & 2.4 & 24.4 \\
\hline & 3 HOSPITAL CLINIC & 9 & 22.0 & 22.0 & 46.3 \\
\hline & 4 HMO & 3 & 7.3 & 7.3 & 53.7 \\
\hline & 5 COMMUNITY HEALTH CENTER & 9 & 22.0 & 22.0 & 75.6 \\
\hline & 6 ACADEMIC HEALTH CENTER & 2 & 4.9 & 4.9 & 80.5 \\
\hline & 7 OTHER & 8 & 19.5 & 19.5 & 100.0 \\
\hline & Total & 41 & 100.0 & 100.0 & \\
\hline
\end{tabular}


Nurse Practitioner Survey of National Asthma Guidelines 26

\begin{tabular}{|c|c|c|c|c|c|}
\hline \multicolumn{6}{|c|}{ A VEADC IM MD DORTIRE } \\
\hline & & Franilancy & Parrant & Valid & C.umulative \\
\hline \multirow{36}{*}{ Valid } & 1 & 3 & 72 & 75 & 75 \\
\hline & 2 & 3 & 73 & 75 & $15 n$ \\
\hline & 3 & 2 & $\Delta a$ & $5 \cap$ & $2 n \cap$ \\
\hline & 4 & 5 & 120 & 125 & 325 \\
\hline & 5 & $\Delta$ & a 8 & $1 \cap n$ & $\Delta 25$ \\
\hline & 6 & $\Delta$ & a 8 & $1 \cap n$ & 525 \\
\hline & 7 & 1 & 24 & 25 & $55 \cap$ \\
\hline & 8 & 3 & 73 & 75 & 6ว 5 \\
\hline & 9 & $n$ & $n$ & $n$ & $n$ \\
\hline & 10 & $\Delta$ & a & $1 \cap n$ & 725 \\
\hline & 11 & 1 & 24 & 25 & $75 n$ \\
\hline & 12 & $n$ & $n$ & $\cap$ & $n$ \\
\hline & 13 & 1 & $2 \Delta$ & 25 & 775 \\
\hline & 14 & $n$ & $n$ & $n$ & $n$ \\
\hline & 15 & $\cap$ & $n$ & $n$ & $n$ \\
\hline & 16 & 1 & 24 & 25 & $8 \cap n$ \\
\hline & 17 & 2 & $\Delta a$ & $5 \cap$ & $85 n$ \\
\hline & 18 & $n$ & $n$ & $n$ & $n$ \\
\hline & 19 & $n$ & $n$ & $n$ & $\cap$ \\
\hline & n & 2 & $\Delta a$ & 50 & an $n$ \\
\hline & 21 & $n$ & $n$ & $n$ & $n$ \\
\hline & 22 & $n$ & $n$ & $n$ & $n$ \\
\hline & 23 & $n$ & $n$ & $n$ & $n$ \\
\hline & 24 & $n$ & $n$ & $n$ & $n$ \\
\hline & 25 & 1 & 24 & 25 & aว 5 \\
\hline & 26 & 1 & 24 & 25 & $a 5 n$ \\
\hline & 27 & 1 & $2 \Delta$ & 25 & a75 \\
\hline & 28 & $n$ & $n$ & $n$ & $n$ \\
\hline & 29 & $n$ & $n$ & $n$ & $n$ \\
\hline & $3 n$ & $n$ & $n$ & $n$ & $n$ \\
\hline & 31 & $n$ & $n$ & $n$ & $\mathrm{n}$ \\
\hline & 32 & $n$ & $n$ & $n$ & $n$ \\
\hline & 33 & $\cap$ & $n$ & $n$ & $\cap$ \\
\hline & 34 & $\cap$ & $n$ & $n$ & $n$ \\
\hline & 35 & 1 & 24 & 25 & $1 \cap \cap n$ \\
\hline & Total & $\Delta \cap$ & 976 & $1 \cap \cap \cap$ & \\
\hline Miscinn & Svatam & 1 & 24 & & \\
\hline Tntal & & $\Delta 1$ & $1 \mathrm{n} \cap \mathrm{n}$ & & \\
\hline
\end{tabular}


Q5 NUMBER OF PATIENTS WITH ASTHMA IN PATIENT ROSTER

\begin{tabular}{|c|c|c|c|c|c|}
\hline & & Frequency & Percent & $\begin{array}{l}\text { Valid } \\
\text { Percent }\end{array}$ & $\begin{array}{l}\text { Cumulative } \\
\text { Percent }\end{array}$ \\
\hline \multirow{23}{*}{ Valid } & 5 & 3 & 7.3 & 12.5 & 12.5 \\
\hline & 10 & 6 & 14.6 & 25.0 & 37.5 \\
\hline & 15 & 0 & 0 & 0 & 0 \\
\hline & 20 & 2 & 4.9 & 8.3 & 45.8 \\
\hline & 25 & 1 & 2.4 & 4.2 & 50.0 \\
\hline & 30 & 1 & 2.4 & 4.2 & 54.2 \\
\hline & 35 & 0 & 0 & 0 & 0 \\
\hline & 40 & 1 & 2.4 & 4.2 & 58.3 \\
\hline & 45 & 0 & 0 & 0 & 0 \\
\hline & 50 & 2 & 4.9 & 8.3 & 66.7 \\
\hline & 75 & 0 & 0 & 0 & 0 \\
\hline & 100 & 5 & 12.2 & 20.8 & 87.5 \\
\hline & 125 & 0 & 0 & 0 & 0 \\
\hline & 150 & 0 & 0 & 0 & 0 \\
\hline & 175 & 0 & 0 & 0 & 0 \\
\hline & 200 & 1 & 2.4 & 4.2 & 91.7 \\
\hline & 225 & 0 & 0 & 0 & 0 \\
\hline & 250 & 0 & 0 & 0 & 0 \\
\hline & 275 & 0 & 0 & 0 & 0 \\
\hline & 300 & 1 & 2.4 & 4.2 & 95.8 \\
\hline & 400 & 0 & 0 & 0 & 0 \\
\hline & 500 & 1 & 2.4 & 4.2 & 100.0 \\
\hline & Total & 24 & 58.5 & 100.0 & \\
\hline Missing & System & 17 & 41.5 & & \\
\hline Total & & 41 & 100.0 & & \\
\hline
\end{tabular}


Q6 USING NATIONAL ASTHMA PRACTICE GUIDELINES

\begin{tabular}{|l|l|r|r|r|r|}
\hline & & Frequency & Percent & $\begin{array}{c}\text { Valid } \\
\text { Percent }\end{array}$ & $\begin{array}{c}\text { Cumulative } \\
\text { Percent }\end{array}$ \\
\hline \multirow{3}{*}{ Valid } & 1 YES & 33 & 80.5 & 82.5 & 82.5 \\
\cline { 2 - 7 } & $\mathbf{2}$ NO & 7 & 17.1 & 17.5 & 100.0 \\
\cline { 2 - 7 } & Total & 40 & 97.6 & 100.0 & \\
\hline Missing & System & 1 & 2.4 & & \\
\hline Total & 41 & 100.0 & & \\
\hline
\end{tabular}

Q7 AWARE NIH GUIDELINES FOR DIAGNOSIS AND
TREATMENT OF ASTHMA WERE UPDATED IN 2002
\begin{tabular}{|l|l|r|r|r|r|}
\hline & & Frequency & Percent & $\begin{array}{c}\text { Valid } \\
\text { Percent }\end{array}$ & $\begin{array}{c}\text { Cumulative } \\
\text { Percent }\end{array}$ \\
\hline \multirow{3}{*}{$\begin{array}{l}\text { Valid } \\
\text { Y YES }\end{array}$} & 36 & 87.8 & 90.0 & 90.0 \\
\hline & 2 NO & 4 & 9.8 & 10.0 & 100.0 \\
\hline & Total & 40 & 97.6 & 100.0 & \\
\hline Missing & System & 1 & 2.4 & & \\
\hline Total & & 41 & 100.0 & & \\
\hline
\end{tabular}

Q8 HAVE A COPY OR ACCESS TO NIH GUIDELINES IN YOUR PRACTICE SETTING

\begin{tabular}{|r|r|r|r|r|r|}
\hline & Frequency & Percent & $\begin{array}{c}\text { Valid } \\
\text { Percent }\end{array}$ & $\begin{array}{c}\text { Cumulative } \\
\text { Percent }\end{array}$ \\
\hline Valid & 1 YES & 32 & 78.0 & 78.0 & 78.0 \\
\hline Total & 9 & 22.0 & 22.0 & 100.0 \\
\hline Total & 41 & 100.0 & 100.0 & \\
\hline
\end{tabular}

Q9A LEARNED OF NIH GUIDELINES - READING A COPY OF GUIDELINES

\begin{tabular}{|l|l|r|r|r|r|}
\hline & & Frequency & Percent & $\begin{array}{c}\text { Valid } \\
\text { Percent }\end{array}$ & $\begin{array}{c}\text { Cumulative } \\
\text { Percent }\end{array}$ \\
\hline Valid & 1 & 19 & 46.3 & 100.0 & 100.0 \\
\hline Missing & System & 22 & 53.7 & & \\
\hline Total & 41 & 100.0 & & \\
\hline
\end{tabular}


Q9B LEARNED OF NIH GUIDELINES - CONTINUING EDUCATION

\begin{tabular}{|l|r|r|r|r|r|}
\hline & & Frequency & Percent & $\begin{array}{c}\text { Valid } \\
\text { Percent }\end{array}$ & $\begin{array}{c}\text { Cumulative } \\
\text { Percent }\end{array}$ \\
\hline Valid & $\mathbf{1}$ & 17 & 41.5 & 100.0 & 100.0 \\
\hline Missing & System & 24 & 58.5 & & \\
\hline Total & 41 & 100.0 & & \\
\hline
\end{tabular}

Q9C LEARNED OF NIH GUIDELINES - JOURNALS

\begin{tabular}{|l|l|r|r|r|r|}
\hline & & Frequency & Percent & $\begin{array}{c}\text { Valid } \\
\text { Percent }\end{array}$ & $\begin{array}{c}\text { Cumulative } \\
\text { Percent }\end{array}$ \\
\hline Valid & $\mathbf{1}$ & 13 & 31.7 & 100.0 & 100.0 \\
\hline Missing & System & 28 & 68.3 & & \\
\hline Total & 41 & 100.0 & & \\
\hline
\end{tabular}

Q9D LEARNED OF NIH GUIDELINES - PHARMACEUTICAL REPRESENTATIVE

\begin{tabular}{|l|l|r|r|r|r|}
\hline & & Frequency & Percent & $\begin{array}{c}\text { Valid } \\
\text { Percent }\end{array}$ & $\begin{array}{c}\text { Cumulative } \\
\text { Percent }\end{array}$ \\
\hline Valid & $\mathbf{1}$ & 4 & 9.8 & 100.0 & 100.0 \\
\hline Missing & System & 37 & 90.2 & & \\
\hline Total & 41 & 100.0 & & \\
\hline
\end{tabular}

Q9E LEARNED OF NIH GUIDELINES - PHYSICIANS

\begin{tabular}{|l|l|r|r|r|r|}
\hline & & Frequency & Percent & $\begin{array}{c}\text { Valid } \\
\text { Percent }\end{array}$ & $\begin{array}{c}\text { Cumulative } \\
\text { Percent }\end{array}$ \\
\hline Valid & 1 & 1 & 2.4 & 100.0 & 100.0 \\
\hline Missing & System & 40 & 97.6 & & \\
\hline Total & 41 & 100.0 & & \\
\hline
\end{tabular}

Q9F LEARNED OF NIH GUIDELINES - OTHER COLLEAGUES

\begin{tabular}{|l|l|r|r|r|r|}
\hline & & Frequency & Percent & $\begin{array}{c}\text { Valid } \\
\text { Percent }\end{array}$ & $\begin{array}{c}\text { Cumulative } \\
\text { Percent }\end{array}$ \\
\hline Valid & 1 & 6 & 14.6 & 100.0 & 100.0 \\
\hline Missing & System & 35 & 85.4 & & \\
\hline Total & 41 & 100.0 & & \\
\hline
\end{tabular}


Q9G LEARNED OF NIH GUIDELINES - OTHER

\begin{tabular}{|l|l|r|r|r|r|}
\hline & & Frequency & Percent & $\begin{array}{c}\text { Valid } \\
\text { Percent }\end{array}$ & $\begin{array}{c}\text { Cumulative } \\
\text { Percent }\end{array}$ \\
\hline Valid 1 & 3 & 7.3 & 100.0 & 100.0 \\
\hline Missing & System & 38 & 92.7 & & \\
\hline Total & 41 & 100.0 & & \\
\hline
\end{tabular}

\section{Q10 GUIDELINES ARE USEFUL TO YOUR PRACTICE}

\begin{tabular}{|c|c|c|c|c|c|}
\hline & & Frequency & Percent & $\begin{array}{l}\text { Valid } \\
\text { Percent }\end{array}$ & $\begin{array}{c}\text { Cumulative } \\
\text { Percent }\end{array}$ \\
\hline & 1 STONGLY DISAGREE & 0 & 0 & 0 & 0 \\
\hline & 2 DISAGREE & 0 & 0 & 0 & 0 \\
\hline \multirow{4}{*}{ Valid } & 3 UNDECIDED & 5 & 12.2 & 12.5 & 12.5 \\
\hline & 4 AGREE & 17 & 41.5 & 42.5 & 55.0 \\
\hline & 5 STRONGLY AGREE & 18 & 43.9 & 45.0 & 100.0 \\
\hline & Total & 40 & 97.6 & 100.0 & \\
\hline Missing & System & 1 & 2.4 & & \\
\hline Total & & 41 & 100.0 & & \\
\hline
\end{tabular}

Q11 YOUR ATTITUDE TOWARDS ASTHMA GUIDELINES ARE POSITIVE

\begin{tabular}{|l|l|r|r|r|r|}
\hline & Frequency & Percent & $\begin{array}{c}\text { Valid } \\
\text { Percent }\end{array}$ & $\begin{array}{c}\text { Cumulative } \\
\text { Percent }\end{array}$ \\
\hline & 1 STRONGLY DISAGREE & 0 & 0 & 0 & 0 \\
\hline & 2 DISAGREE & 0 & 0 & 0 & 0 \\
\hline & 3 UNDECIDED & 1 & 2.4 & 2.5 & 2.5 \\
\hline \multirow{3}{*}{ Valid } & $\mathbf{4}$ AGREE & 22 & 53.7 & 55.0 & 57.5 \\
\cline { 2 - 7 } & $\mathbf{5}$ STRONGLY AGREE & 17 & 41.5 & 42.5 & 100.0 \\
\hline & Total & 40 & 97.6 & 100.0 & \\
\hline \multirow{2}{*}{ Missing } & System & 1 & 2.4 & & \\
\hline Total & & 41 & 100.0 & & \\
\hline
\end{tabular}


Q12 ATTITUDES OF YOUR COLLEAGUES REGARDING GUIDELINES ARE POSITIVE

\begin{tabular}{|l|l|r|r|r|r|}
\hline & & Frequency & Percent & $\begin{array}{c}\text { Valid } \\
\text { Percent }\end{array}$ & $\begin{array}{c}\text { Cumulative } \\
\text { Percent }\end{array}$ \\
\hline & 1 STRONGLY DISAGREE & 0 & 0 & 0 & 0 \\
\hline & 2 DISAGREE & 0 & 0 & 0 & 0 \\
\hline & 3 UNDECIDED & 6 & 14.6 & 15.0 & 15.0 \\
\hline \multirow{3}{*}{ Valid } & 4 AGREE & 26 & 63.4 & 65.0 & 80.0 \\
\cline { 2 - 7 } & $\mathbf{5}$ STRONGLY AGREE & 8 & 19.5 & 20.0 & 100.0 \\
\hline & Total & 40 & 97.6 & 100.0 & \\
\hline \multirow{2}{*}{ Missing } & System & 1 & 2.4 & & \\
\hline Total & & 41 & 100.0 & & \\
\hline
\end{tabular}

Q13 IMPLEMENTATION OF WELL-DEVELOPED GUIDELINES COULD IMPROVE QUALITY OF ASTHMATICS CARE

\begin{tabular}{|c|c|c|c|c|c|}
\hline & & Frequency & Percent & $\begin{array}{l}\text { Valid } \\
\text { Percent }\end{array}$ & $\begin{array}{l}\text { Cumulative } \\
\text { Percent }\end{array}$ \\
\hline & 1 STRONGLY DISAGREE & 0 & 0 & 0 & 0 \\
\hline & 2 DISAGREE & 0 & 0 & 0 & 0 \\
\hline \multirow{4}{*}{ Valid } & 3 UNDECIDED & 2 & 4.9 & 5.0 & 5.0 \\
\hline & 4 AGREE & 20 & 48.8 & 50.0 & 55.0 \\
\hline & 5 STRONGLY AGREE & 18 & 43.9 & 45.0 & 100.0 \\
\hline & Total & 40 & 97.6 & 100.0 & \\
\hline Missing & System & 1 & 2.4 & & \\
\hline \multicolumn{2}{|l|}{ Total } & 41 & 100.0 & & \\
\hline
\end{tabular}

Q14 GUIDELINES DENY THE INDIVIDUALITY OF PATIENTS

\begin{tabular}{|c|c|c|c|c|c|}
\hline & & Frequency & Percent & $\begin{array}{l}\text { Valid } \\
\text { Percent }\end{array}$ & $\begin{array}{c}\text { Cumulative } \\
\text { Percent }\end{array}$ \\
\hline \multirow{6}{*}{ Valid } & 1 STRONGLY DISAGREE & 10 & 24.4 & 25.0 & 25.0 \\
\hline & 2 DISAGREE & 19 & 46.3 & 47.5 & 72.5 \\
\hline & 3 UNDECIDED & 7 & 17.1 & 17.5 & 90.0 \\
\hline & 4 AGREE & 3 & 7.3 & 7.5 & 97.5 \\
\hline & 5 STRONGLY AGREE & 1 & 2.4 & 2.5 & 100.0 \\
\hline & Total & 40 & 97.6 & 100.0 & \\
\hline Missing & System & 1 & 2.4 & & \\
\hline Total & & 41 & 100.0 & & \\
\hline
\end{tabular}


Q15 ASTHMA GUIDELINES ARE EVIDENCE-BASED

\begin{tabular}{|c|c|c|c|c|c|}
\hline & & Frequency & Percent & $\begin{array}{l}\text { Valid } \\
\text { Percent }\end{array}$ & $\begin{array}{c}\text { Cumulative } \\
\text { Percent }\end{array}$ \\
\hline & 1 STONGLY DISAGREE & 0 & 0 & 0 & 0 \\
\hline \multirow{5}{*}{ Valid } & 2 DISAGREE & 2 & 4.9 & 5.0 & 5.0 \\
\hline & 3 UNDECIDED & 6 & 14.6 & 15.0 & 20.0 \\
\hline & 4 AGREE & 23 & 56.1 & 57.5 & 77.5 \\
\hline & 5 STRONGLY AGREE & 9 & 22.0 & 22.5 & 100.0 \\
\hline & Total & 40 & 97.6 & 100.0 & \\
\hline Missing & System & 1 & 2.4 & & \\
\hline Total & & 41 & 100.0 & & \\
\hline
\end{tabular}

\section{Q16 GUIDELINES ARE EASY TO FOLLOW}

\begin{tabular}{|c|c|c|c|c|c|}
\hline & & Frequency & Percent & $\begin{array}{l}\text { Valid } \\
\text { Percent }\end{array}$ & $\begin{array}{c}\text { Cumulative } \\
\text { Percent }\end{array}$ \\
\hline & 1 STRONGLY DISAGREE & 0 & 0 & 0 & 0 \\
\hline \multirow{5}{*}{ Valid } & 2 DISAGREE & 2 & 4.9 & 5.0 & 5.0 \\
\hline & 3 UNDECIDED & 4 & 9.8 & 10.0 & 15.0 \\
\hline & 4 AGREE & 26 & 63.4 & 65.0 & 80.0 \\
\hline & 5 STRONGLY AGREE & 8 & 19.5 & 20.0 & 100.0 \\
\hline & Total & 40 & 97.6 & 100.0 & \\
\hline Missing & System & 1 & 2.4 & & \\
\hline Total & & 41 & 100.0 & & \\
\hline
\end{tabular}

Q17 ASTHMA GUIDELINES ARE HELPFUL TO YOUR PRACTICE

\begin{tabular}{|c|c|c|c|c|c|}
\hline & & Frequency & Percent & \begin{tabular}{|c|} 
Valid \\
Percent
\end{tabular} & $\begin{array}{c}\text { Cumulative } \\
\text { Percent }\end{array}$ \\
\hline & 1 STONGLY DISAGREE & 0 & 0 & 0 & 0 \\
\hline & 2 DISAGREE & 0 & 0 & 0 & 0 \\
\hline \multirow{4}{*}{ Valid } & 3 UNDECIDED & 5 & 12.2 & 12.5 & 12.5 \\
\hline & 4 AGREE & 22 & 53.7 & 55.0 & 67.5 \\
\hline & 5 STRONGLY AGREE & 13 & 31.7 & 32.5 & 100.0 \\
\hline & Total & 40 & 97.6 & 100.0 & \\
\hline Missing & System & 1 & 2.4 & & \\
\hline Total & & 41 & 100.0 & & \\
\hline
\end{tabular}


Q18 INQUIRING ABOUT A PATIENT'S SMOKING STATUS IS IMPORTANT

\begin{tabular}{|c|c|c|c|c|c|}
\hline & & Frequency & Percent & $\begin{array}{c}\text { Valid } \\
\text { Percent }\end{array}$ & $\begin{array}{l}\text { Cumulative } \\
\text { Percent }\end{array}$ \\
\hline & 1 STRONGLY DISAGREE & 0 & 0 & 0 & 0 \\
\hline & 2 DISAGREE & 0 & 0 & 0 & 0 \\
\hline & 3 UNDECIDED & 0 & 0 & 0 & 0 \\
\hline \multirow{3}{*}{ Valid } & 4 AGREE & 8 & 19.5 & 20.0 & 20.0 \\
\hline & 5 STRONGLY AGREE & 32 & 78.0 & 80.0 & 100.0 \\
\hline & Total & 40 & 97.6 & 100.0 & \\
\hline Missing & System & 1 & 2.4 & & \\
\hline Total & & 41 & 100.0 & & \\
\hline
\end{tabular}

Q19 COUNSELING PARENTS TO QUIT SMOKING IS IMPORTANT

\begin{tabular}{|c|c|c|c|c|c|}
\hline & & Frequency & Percent & $\begin{array}{l}\text { Valid } \\
\text { Percent }\end{array}$ & $\begin{array}{c}\text { Cumulative } \\
\text { Percent }\end{array}$ \\
\hline & 1 STRONGLY DISAGREE & 0 & 0 & 0 & 0 \\
\hline & 2 DISAGREE & 0 & 0 & 0 & 0 \\
\hline & 3 UNDECIDED & 0 & 0 & 0 & 0 \\
\hline \multirow{3}{*}{ Valid } & 4 AGREE & 8 & 19.5 & 20.0 & 20.0 \\
\hline & 5 STRONGLY AGREE & 32 & 78.0 & 80.0 & 100.0 \\
\hline & Total & 40 & 97.6 & 100.0 & \\
\hline Missing & System & 1 & 2.4 & & \\
\hline Total & & 41 & 100.0 & & \\
\hline
\end{tabular}

Q20 PERCENTAGE OF PEDIATRIC ASTHMA PATIENTS WITH DAILY SYMPTOMS GREATER THAN 5 YEARS OF AGE YOU INSTRUCT TO MONITOR DAILY EXPIRATORY PEAK FLOW READING

\begin{tabular}{|c|c|c|c|c|c|}
\hline & & Frequency & Percent & $\begin{array}{l}\text { Valid } \\
\text { Percent }\end{array}$ & $\begin{array}{l}\text { Cumulative } \\
\text { Percent }\end{array}$ \\
\hline \multirow{6}{*}{ Valid } & $10-20 \%$ & 16 & 39.0 & 48.5 & 48.5 \\
\hline & $2 \quad 21-40 \%$ & 1 & 2.4 & 3.0 & 51.5 \\
\hline & $3 \quad 41-60 \%$ & 3 & 7.3 & 9.1 & 60.6 \\
\hline & $4 \quad 61-80 \%$ & 3 & 7.3 & 9.1 & 69.7 \\
\hline & $5 \quad 81-100 \%$ & 10 & 24.4 & 30.3 & 100.0 \\
\hline & Total & 33 & 80.5 & 100.0 & \\
\hline Missing & System & 8 & 19.5 & & \\
\hline Total & & 41 & 100.0 & & \\
\hline
\end{tabular}


Q21 PERCENTAGE OF PEDIATRIC ASTHMA PATIENTS WITH DAILY SYMPTOMS YOU INSTRUCT TO AVOID EXPOSURE TO TOBACCO SMOKE

\begin{tabular}{|c|c|c|c|c|c|}
\hline & & Frequency & Percent & $\begin{array}{l}\text { Valid } \\
\text { Percent }\end{array}$ & $\begin{array}{c}\text { Cumulative } \\
\text { Percent }\end{array}$ \\
\hline \multirow{6}{*}{ Valid } & $10-20 \%$ & 2 & 4.9 & 5.7 & 5.7 \\
\hline & $2 \quad 21-40 \%$ & 0 & 0 & 0 & 0 \\
\hline & $3 \quad 41-60 \%$ & 0 & 0 & 0 & 0 \\
\hline & $4 \quad 61-80 \%$ & 3 & 7.3 & 8.6 & 14.3 \\
\hline & $5 \quad 81-100 \%$ & 30 & 73.2 & 85.7 & 100.0 \\
\hline & Total & 35 & 85.4 & 100.0 & \\
\hline Missing & System & 6 & 14.6 & & \\
\hline Total & & 41 & 100.0 & & \\
\hline
\end{tabular}

Q22 PERCENTAGE OF PEDIATRIC PATIENTS WITH MILD PERSISTENT ASTHMA YOU FURNISH WITH INHALED CORTICOSTERIODS

\begin{tabular}{|c|c|c|c|c|c|}
\hline & & Frequency & Percent & $\begin{array}{c}\text { Valid } \\
\text { Percent }\end{array}$ & $\begin{array}{l}\text { Cumulative } \\
\text { Percent }\end{array}$ \\
\hline \multirow{6}{*}{ Valid } & $10-20 \%$ & 4 & 9.8 & 11.8 & 11.8 \\
\hline & $2 \quad 21-40 \%$ & 1 & 2.4 & 2.9 & 14.7 \\
\hline & $3 \quad 41-60 \%$ & 3 & 7.3 & 8.8 & 23.5 \\
\hline & $4 \quad 61-80 \%$ & 10 & 24.4 & 29.4 & 52.9 \\
\hline & $5 \quad 81-100 \%$ & 16 & 39.0 & 47.1 & 100.0 \\
\hline & Total & 34 & 82.9 & 100.0 & \\
\hline Missing & System & 7 & 17.1 & & \\
\hline Total & & 41 & 100.0 & & \\
\hline
\end{tabular}




\begin{tabular}{|c|c|c|c|c|c|}
\hline \multicolumn{6}{|c|}{$\begin{array}{l}\text { Q23 PERCENTAGE OF PEDIATRIC PATIENTS WITH MILD } \\
\text { PERSISTENT ASTHMA YOU FURNISH CROMOLYN }\end{array}$} \\
\hline & & Frequency & Percent & $\begin{array}{l}\text { Valid } \\
\text { Percent }\end{array}$ & $\begin{array}{l}\text { Cumulative } \\
\text { Percent }\end{array}$ \\
\hline \multirow{6}{*}{ Valid } & $10-20 \%$ & 24 & 58.5 & 68.6 & 68.6 \\
\hline & $2 \quad 21-40 \%$ & 4 & 9.8 & 11.4 & 80.0 \\
\hline & $341-60 \%$ & 4 & 9.8 & 11.4 & 91.4 \\
\hline & $461-80 \%$ & 3 & 7.3 & 8.6 & 100.0 \\
\hline & $5 \quad 81-100 \%$ & 0 & 0 & 0 & 0 \\
\hline & Total & 35 & 85.4 & 100.0 & \\
\hline Missing & System & 6 & 14.6 & & \\
\hline Total & & 41 & 100.0 & & \\
\hline
\end{tabular}

\begin{tabular}{|c|c|c|c|c|c|}
\hline \multicolumn{6}{|c|}{$\begin{array}{l}\text { Q24 PERCENTAGE OF PEDIATRIC PATIENTS WITH MILD } \\
\text { PERSISTENT ASTHMA YOU FURNISH WITH A LEUKOTRIENE } \\
\text { RECEPTOR ANTAGONISTS }\end{array}$} \\
\hline & & Frequency & Percent & $\begin{array}{l}\text { Valid } \\
\text { Percent }\end{array}$ & $\begin{array}{c}\text { Cumulative } \\
\text { Percent }\end{array}$ \\
\hline \multirow{6}{*}{ Valid } & $10-20 \%$ & 18 & 43.9 & 54.5 & 54.5 \\
\hline & $2 \quad 21-40 \%$ & 7 & 17.1 & 21.2 & 75.8 \\
\hline & $3 \quad 41-60 \%$ & 3 & 7.3 & 9.1 & 84.8 \\
\hline & $461-80 \%$ & 4 & 9.8 & 12.1 & 97.0 \\
\hline & $5 \quad 81-100 \%$ & 1 & 2.4 & 3.0 & 100.0 \\
\hline & Total & 33 & 80.5 & 100.0 & \\
\hline Missing & System & 8 & 19.5 & & \\
\hline Total & & 41 & 100.0 & & \\
\hline
\end{tabular}


Q25 PERCENTAGE OF PEDIATRIC ASTHMA PATIENTS WITH MODERATE PERSISTENT ASTHMA YOU FURNISH DAILY MEDICATIONS

\begin{tabular}{|c|c|c|c|c|c|}
\hline & & Frequency & Percent & $\begin{array}{l}\text { Valid } \\
\text { Percent }\end{array}$ & $\begin{array}{l}\text { Cumulative } \\
\text { Percent }\end{array}$ \\
\hline \multirow{6}{*}{ Valid } & $10-20 \%$ & 4 & 9.8 & 11.4 & 11.4 \\
\hline & $2 \quad 21-40 \%$ & 0 & 0 & 0 & 0 \\
\hline & $3 \quad 41-60 \%$ & 3 & 7.3 & 8.6 & 20.0 \\
\hline & $461-80 \%$ & 6 & 14.6 & 17.1 & 37.1 \\
\hline & $5 \quad 81-100 \%$ & 22 & 53.7 & 62.9 & 100.0 \\
\hline & Total & 35 & 85.4 & 100.0 & \\
\hline Missing & System & 6 & 14.6 & & \\
\hline Total & & 41 & 100.0 & & \\
\hline
\end{tabular}

Q26 PERCENTAGE OF PEDIATRIC PATIENTS WITH MODERATE PERSISTENT ASTHMA YOU FURNISH WITH A LEUKOTRIENE RECEPTOR ANTAGONISTS

\begin{tabular}{|l|l|r|r|r|r|}
\hline & & Frequency & Percent & $\begin{array}{r}\text { Valid } \\
\text { Percent }\end{array}$ & $\begin{array}{c}\text { Cumulative } \\
\text { Percent }\end{array}$ \\
\hline & $\mathbf{1} \quad \mathbf{0 - 2 0} \%$ & 14 & 34.1 & 40.0 & 40.0 \\
\hline $\mathbf{2} \quad \mathbf{2 1 - 4 0 \%}$ & 5 & 12.2 & 14.3 & 54.3 \\
\hline \multirow{2}{*}{ Valid } & $\mathbf{3} \quad \mathbf{4 1 - 6 0 \%}$ & 8 & 19.5 & 22.9 & 77.1 \\
\hline & $\mathbf{4} \quad \mathbf{6 1 - 8 0} \%$ & 3 & 7.3 & 8.6 & 85.7 \\
\hline & $\mathbf{5} \quad \mathbf{8 1 - 1 0 0} \%$ & 5 & 12.2 & 14.3 & 100.0 \\
\hline & Total & 35 & 85.4 & 100.0 & \\
\hline Missing & System & 6 & 14.6 & & \\
\hline Total & & 41 & 100.0 & & \\
\hline
\end{tabular}




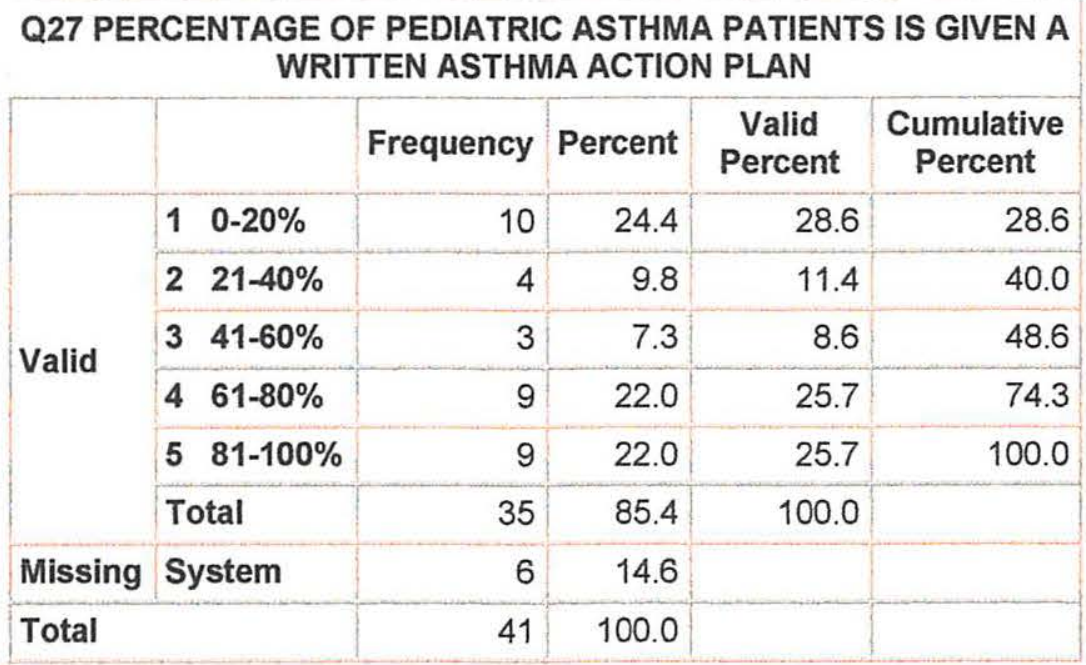

Q28 PERCENTAGE OF PEDIATRIC ASTHMA PATIENTS IS EDUCATED ON THEIR DISEASE

\begin{tabular}{|c|c|c|c|c|c|}
\hline & & Frequency & Percent & $\begin{array}{l}\text { Valid } \\
\text { Percent }\end{array}$ & $\begin{array}{c}\text { Cumulative } \\
\text { Percent }\end{array}$ \\
\hline \multirow{6}{*}{ Valid } & $10-20 \%$ & 2 & 4.9 & 5.7 & 5.7 \\
\hline & $2 \quad 21-40 \%$ & 2 & 4.9 & 5.7 & 11.4 \\
\hline & $3 \quad 41-60 \%$ & 1 & 2.4 & 2.9 & 14.3 \\
\hline & $461-80 \%$ & 6 & 14.6 & 17.1 & 31.4 \\
\hline & $5 \quad 81-100 \%$ & 24 & 58.5 & 68.6 & 100.0 \\
\hline & Total & 35 & 85.4 & 100.0 & \\
\hline Missing & System & 6 & 14.6 & & \\
\hline Total & & 41 & 100.0 & & \\
\hline
\end{tabular}

Q29 DO YOU INTEND TO USE THE ASTHMA GUIDELINES

\begin{tabular}{|l|l|r|r|r|r|}
\hline & & Frequency & Percent & $\begin{array}{c}\text { Valid } \\
\text { Percent }\end{array}$ & $\begin{array}{c}\text { Cumulative } \\
\text { Percent }\end{array}$ \\
\hline Valid & 1 YES & 36 & 87.8 & 97.3 & 97.3 \\
\hline & 2 NO & 1 & 2.4 & 2.7 & 100.0 \\
\hline & Total & 37 & 90.2 & 100.0 & \\
\hline Missing & System & 4 & 9.8 & & \\
\hline Total & & 41 & 100.0 & & \\
\hline
\end{tabular}


Nurse Practitioner Survey of National Asthma Guidelines 38

Appendix B

Questionnaire 


\section{Survey of Attitudes of Nurse Practitioners' Regarding the NIH Guidelines for the Diagnosis and Treatment of Asthma}

All of the questions for this survey revolve around your practices, knowledge and attitudes regarding the National Heart, Lung and Blood Institutes, National Asthma Education and Prevention Program Expert Panel Report 2, 1997 and the Update on Selected Topics, 2002.

For each item below, darken the oval next to the choice you select.

\section{DEMOGRAPHICS}

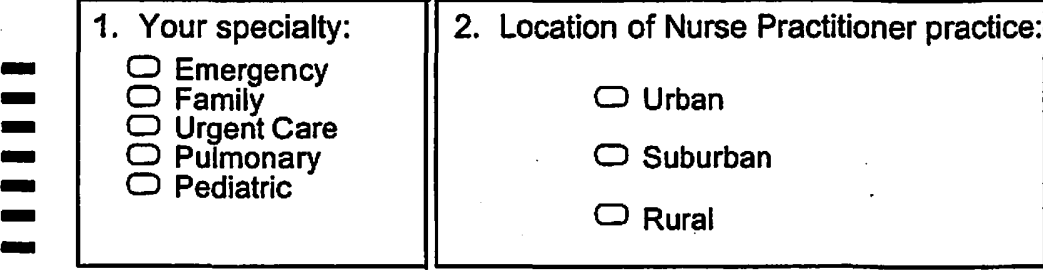

4. Total years in Nurse Practitioner practice:
3. Type of Nurse Practitioner practice at this time:

$\square$ Group
Solo
$\bigcirc$ Hospital Clinic
$\square$ HMO
$\varnothing$ Community health center
$\varnothing$ Academic health center
$\square$ Other

5. How many patients with

. asthma are in your patient roster?

6. Are you using the national asthma practice guidelines? $\square$ Yes $\square$ No

7. Are you aware that the NIH Guidelines for the diagnosis and treatment of asthma were updated in 2002? OYes ONo

8. Do you have a copy or access to the NIH Guidelines for the diagnosis and treatment of asthma available to you in your practice setting? $\bigcirc$ Yes $\triangle$ No

9. How did you learn of the NIH Guidelines for the diagnosis and treatment of asthma?

Reading a copy of the NIH Guidelines for the diagnosis and treatment of asthma

Continuing education

Journals

Pharmaceutical representative

$\checkmark$ Physicians

Other colleagues

Other

Please indicate your level of agreement/disagreement with each of the following items.

10. These guidelines are useful to your practice.

Strongly

Disagre

Disagree

0

Undecided

Agree

Strongly

11. Your attitude towards the asthma guidelines are positive.

12. The attitudes of your colleagues regarding the asthma guidelines are positive.

13. The implementation of well-developed guidelines could improve the quality of asthmatics care.

14. Guidelines deny the individuality of patients.

15. The asthma guidelines are evidence-based.

16. The guidelines are easy to follow.

17. The asthma guidelines are helpful to your practice.

18. Inquiring about a parent's smoking status is important.

19. Counseling parents to quit smoking is important. 


\section{What percentage of pediatric.....}

20. asthma patients with daily symptoms ( $>5$ years of age) do you instruct to monitor daily expiratory peak flow reading?

21. asthma patients with daily symptoms do you instruct to avoid exposure to tobacco smoke?

22. patients with mild persistent asthma do you furnish with inhaled corticosteriods?

23. patients with mild persistent asthma do you furnish cromolyn?

24. patients with mild persistent asthma do you furnish with a leukotriene receptor antagonists?

25. asthma patients with moderate persistent asthma do you furnish daily medications?

26. patients with moderate persistent asthma do you furnish with a leukotriene receptor antagonists?

27. asthma patients is given a written asthma action plan?

28. asthma patients is educated on their disease?

29. Do you intend to use the asthma guidelines? $\square$ Yes $\square$ No

\begin{tabular}{|c|c|c|c|c|}
\hline$\stackrel{0-20 \%}{\square}$ & $\stackrel{21-40 \%}{\square}$ & $\stackrel{41-60 \%}{\square}$ & $\stackrel{61-80 \%}{\square}$ & $\stackrel{81-100 \%}{\square}$ \\
\hline$\square$ & 0 & 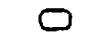 & $\oslash$ & $\square$ \\
\hline$\square$ & $\varnothing$ & $\square$ & 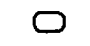 & $\varnothing$ \\
\hline$\oslash$ & $\varnothing$ & $\varnothing$ & $\varnothing$ & $\varnothing$ \\
\hline$\square$ & 0 & $\oslash$ & $\varnothing$ & $\varnothing$ \\
\hline$\oslash$ & $\varnothing$ & $\square$ & $\varnothing$ & $\square$ \\
\hline$\varnothing$ & $\oslash$ & $\oslash$ & $\oslash$ & $\oslash$ \\
\hline$\oslash$ & $\square$ & $\square$ & $\square$ & $\square$ \\
\hline$\varnothing$ & $\bullet$ & $\square$ & $\square$ & 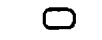 \\
\hline
\end{tabular}

Thank you for your participation!

Please return your completed survey in the enclosed envelope to: 


\section{Appendix C}

July 29,2003

Michael Cabana, MD, MPH

Division of General Pediatrics

University of Michigan School of Medicine

Dr. Cabana

I am a graduate student at San Jose State University in the Family Nurse Practitioner Program. To fulfill the requirements for the Master of Science degree in Nursing, I need to do research for my master's project. I plan to conduct my study of nurse practitioners managing pediatric asthma patients and investigate their practices, knowledge and attitudes towards the national asthma guidelines

I am asking for permission to use the questionnaire that you and your colleagues used in your article "Reasons for Pediatrician nonadherence to asthma guidelines" published in the Archives of Pediatric \& Adolescent Medicine, published September 2001. The questionnaire will be adapted fit to my quantitative survey questionnaire of nurse practitioners treating pediatric asthma patients.

If you have any questions about this study, I will be happy to talk to you. I can be reached at home

$$
\text { My mailing address is }
$$

or email me at

$$
\text { I appreciate your time concerning this matter. I look forward to hearing from }
$$
you soon.

Sincerely,

Colleen M. Hughes RN, BSN 


\section{Appendix C}

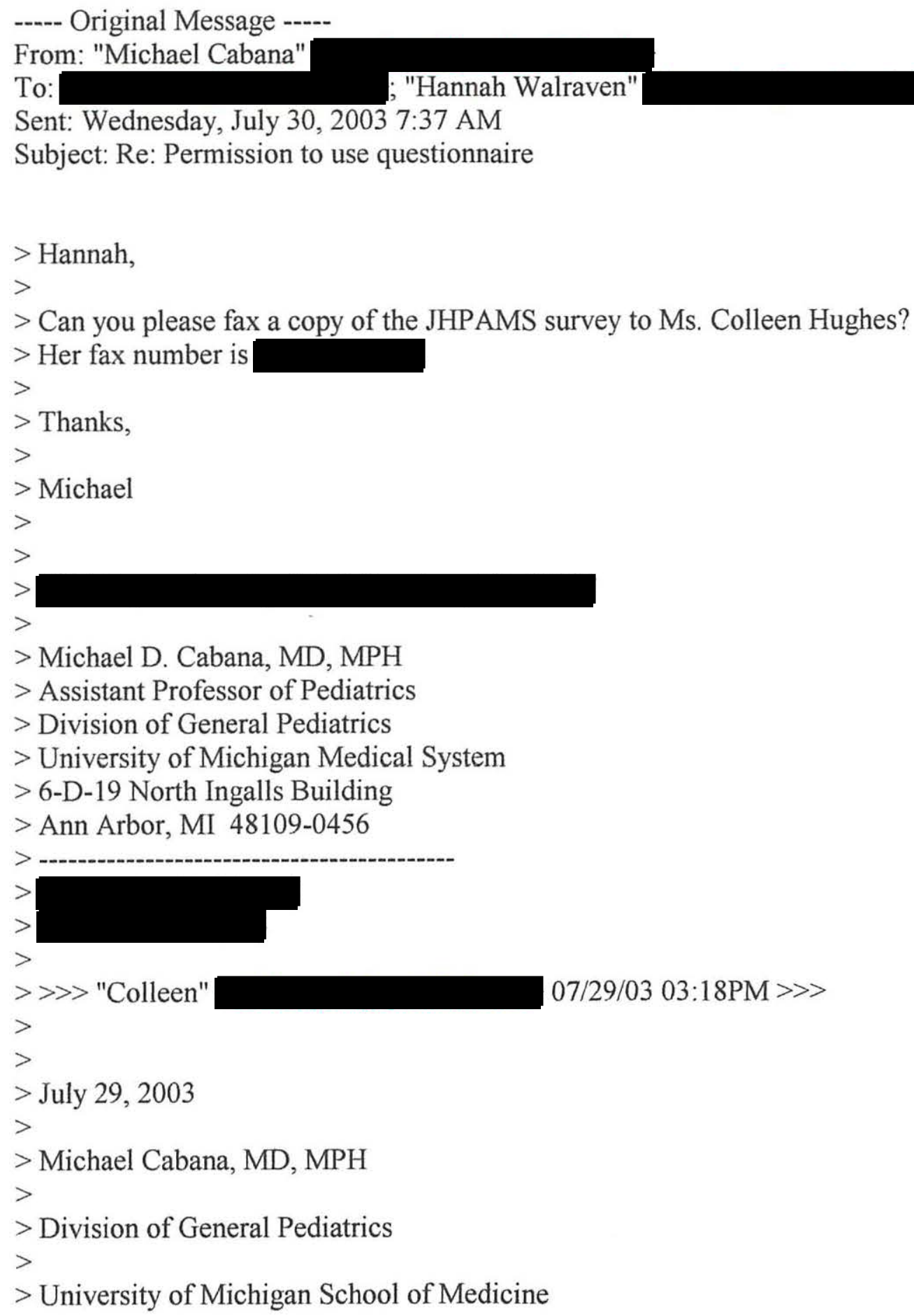




\section{Appendix D}

\section{Pediatric Asthma Survey}

September 1, 2004

\section{Informed Consent Letter}

Dear Nurse Practitioner:

You are invited to take part in a survey about Pediatric asthma care in your current practices. You are eligible to participate in the study if you are currently practicing in: Emergency Medicine, Family Practice, Urgent Care, Pulmonary or Pediatric Practice. The purpose of this study is to understand asthma practice and opinions concerning the use of the National Asthma Guidelines. The survey is expected to take approximately 510 minutes to complete. The findings of this research may help guide future pediatric asthma practice and your participation is very much appreciated.

- Please complete this survey and place it in the enclosed return addressed envelope with in 2 weeks time.

Completion of this survey is voluntary, you may decline to participate in the study without penalty, and you may skip any question that you feel uncomfortable answering. There are no known risks to you as a participant in this study, and your response will be anonymous. If study results are published, no information will be included that could identify any respondent. By mailing the completed survey, you are consenting to participate in this study. Please keep the single sheet copy of this Informed Consent Letter - Participant's Copy for your records.

If you have any questions about this study, I will be happy to talk to you. I can be reached at Complaints about this research may be presented to Dr. Elizabeth Dietz, my project advisor at If you have questions about research subjects' rights, or in the event of a research related injury, please contact Nabil Imrahim, $\mathrm{PhD}$., and Associate Vice President for Graduate Studies and Research at

Many thanks for your time,

Colleen M. Hughes RN, BSN

Graduate Student

School of Nursing

San Jose State University 
Nurse Practitioner Survey of National Asthma Guidelines 42

Appendix E

\section{Conflict-of-Interest Statement}

No Relationship exists between any of the authors and any commercial entity or product mentioned in this manuscript that might represent a conflict of interest. No inducements have been made by any commercial entity to submit the manuscript for publication. 